$\mathrm{A} J \mathrm{H}$

Article history :

Received : 21.08.2014

Accepted : 30.11.2014
Members of the Research Forum

Associated Authors:

Krishi Vigyan Kendra Anogi, Jalalabad

KANNAUJ (U.P.) INDIA

Email : amarvk@yahoo.co.in

Author for correspondence :

R.A. SINGH

C.S. Azad University of Agriculture

and Technology, KANPUR (U.P.) INDIA

Email : rasinghcsau@gmail.com
THE ASIAN JOURNAL OF HORTICULTURE

Volume 9 | Issue 2 | Dec., 2014 | 520-522

Visit us -www.researchjournal.co.in
RESEARCH NOTE

DOI : 10.15740/HAS/TAJH/9.2/520-522

\title{
Studies of plantation of different size of onion sets in Kharif season
}

\section{AMAR SINGH ${ }^{1}$ AND R.A. SINGH}

ABSTRACT : The on farm trial was carried out during rainy season of 2009-10 at farmers fields of Kannauj district. The pilot area situated in the catchments area of river kali. For assessment of different size of onion sets plantation during Kharif season, the use of sets size was refined with the inclusion of small size onion sets. The mature onion bulbs harvested as $182.60 \mathrm{q} / \mathrm{ha}$ from plantation of large size sets of onion. The bulbs yield of onion was recorded as $194.80 \mathrm{q} / \mathrm{ha}$ with plantation of medium size onion sets. The highest yield of $213.40 \mathrm{q} / \mathrm{ha}$ was weighed under plantation of small size onion sets during Kharif season. The yield contributing traits were concordance to its yield. The higher gross return of Rs. 426800/ha, net return of Rs. 359086/ha and BCR of 1:6.30 computed under the plantation of small size sets of onion over other two treatments. Therefore, for obtaining the highest yield and maximum net return from Kharif onion, the farmers were advocated for the use of small size onion sets (between 2.0-2.5g).

KEY WORDS : Asessment, Refinement, Catchments area, Onion sets, Trample

HOW TO CITE THIS ARTICLE : Singh, Amar and Singh, R.A. (2014). Studies on plantation of different size of onion sets in Kharif season. Asian J. Hort., 9(2) : 520-522. 